\title{
André Benhaïm, "Panim”. Visages de Proust
}

\section{Emanuele Kanceff}

\section{(2) OpenEdition}

\section{Journals}

\section{Edizione digitale}

URL: http://journals.openedition.org/studifrancesi/27986

DOI: 10.4000/studifrancesi.27986

ISSN: 2427-5856

\section{Editore}

Rosenberg \& Sellier

\section{Edizione cartacea}

Data di pubblicazione: 31 décembre 2006

Paginazione: 635

ISSN: 0039-2944

\section{Notizia bibliografica digitale}

Emanuele Kanceff, «André Benhaïm, "Panim". Visages de Proust », Studi Francesi [Online], 150 (L | III) | 2006, online dal 30 novembre 2015, consultato il 08 novembre 2020. URL : http://

journals.openedition.org/studifrancesi/27986 ; DOI : https://doi.org/10.4000/studifrancesi.27986

\section{Questo documento è stato generato automaticamente il 8 novembre 2020.}

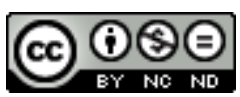

Studi Francesi è distribuita con Licenza Creative Commons Attribuzione - Non commerciale - Non opere derivate 4.0 Internazionale. 


\title{
André Benhaïm, "Panim". Visages de Proust
}

\author{
Emanuele Kanceff
}

\section{NOTIZIA}

ANDRÉ BENHAÏM, "Panim”. Visages de Proust, Villeneuve d'Ascq, Presses Universitaires du Septentrion, 2006, pp. 322.

Questo libro si potrebbe definire un'abile e multiforme orchestrazione di variazioni sul tema del volto in genere e del volto in Proust, in particolare nella concezione proustiana di grappoli di volti sovrapposti che si situano su piani diversi e che non si possono vedere in simultanea. Questo "volto dell'uomo" proustiano, questo "panim" come dicono gli israeliti, è sempre un insieme di facce al plurale ed è inseguito, indagato, evocato attraverso i testi, come se gli enigmi dei volti fossero l'espressione degli enigmi della Recherche. Si passa così naturalmente, in questa lettura proustiana, dai volti da museo ai volti in immagini poetiche, dalle immagini della notte ai volti dell'altrove, dai libri d'ombra alla fotografia, dai volti museali a quelli familiari, della nonna, della storia; dal volto di Swann a quello materno. 